УДК: 339.138

Язвінська Н.В.

канд. економ. наук, доцент

Тимченко А.B.

Національний технічний університет Украйни «КПI»

\title{
ЕВОЛЮЦІЯ В УПРАВЛІННІ КОМПЛЕКСОМ МАРКЕТИНГУ: ЗАСТОСУВАННЯ МОДЕЛІ «7Р» НА ПІДПРИЕМСТВАХ ПРОМИСЛОВИХ ПРАЛЕНЬ
}

\section{ЭВОЛЮЦИЯ В УПРАВЛЕНИИ КОМПЛЕКСОМ МАРКЕТИНГА: ПРИМЕНЕНИЕ МОДЕЛИ «7Р» НА ПРЕДПРИЯТИЯХ ПРОМЫШЛЕННЫХ ПРАЧЕЧНЫХ}

\author{
EVOLUTION IN THE MANAGEMENT OF THE MARKETING MIX: THE \\ APPLICATION OF THE MODEL OF THE "7P" AT INDUSTRIAL LAUNDRIES
}

В статті досліджено еволюцію концепиій управління комплексом маркетингу. Доведено дочільність використання комплексу маркетингу «7Р» для ринку послуг. Через швидкі зміни ринкового середовища та споживчих изінностей покупиів, а також відповідно до специфіки ринку послуг, розиирений комплекс маркетингу «7P» поступово витісняє комплекс «4Р», так як краще відповідає особливостям сфери послуг. Запропоновано авторський підхід до аналізу ефективності комплексу маркетингу підприємства за допомогою поетапного розгляду взаємозв'язку елементів комплексу маркетингу та взаємодї зі споживачем у прочесі прийняття ним рішення про покупку. Розкрито особливості роботи із трьома внутрішніми елементами комплексу маркетингу - процес, фізичний атрибут, персонал. Запропоновано ряд заходів з удосконалення процесу надання послуги та методичне забезпечення для аналізу роботи персоналу підприємства відповідно до розробленого комплексу маркетингу. 3 метою удосконалення процесу управління споживчою цінністю запропоновано структурно-логічну схему, яка наводить послідовність дій, яких потребує процес удосконалення комплексу маркетингу підприємства на ринку послуг.

Ключові слова: комплекс маркетингу, ринок послуг, товар, ціна, розподіл, просування, персонал, фізичний атрибут, процес.

В статье исследована эволющия кониепщий комплекса маркетинга. Быстрые изменения рыночной среды и потребительских ценностей покупателей, а также специфика рынка услуг, определяет постепенное вытеснение традиционного комплекса «4Р» расширенным комплексом маркетинга «7Р», который лучше соответствует особенностям сферы услуг. Доказана иелесообразность использования комплекса маркетинга «7Р» для рынка услуг. Предложен авторский подход $\kappa$ анализу эффрективности комплекса маркетинга предприятия $c$ помощьюю поэтапного рассмотрения взаимосвязи элементов комплекса и взаимодействия с потребителем в процессе принятия им решения о покупке. Рассмотрены особенности работы с тремя внутренними элементами комплекса маркетинга - прочесс, физический атрибут, персонал. Предложен ряд мероприятий по совершенствованию процесса предоставления услуги и методическое обеспечение для анализа работы персонала предприятия в 
соответствии с разработанным комплексом маркетинга. Сформирована структурнологическая схема процесса совершенствование комплекса маркетинга предприятия на рынке услуг. С целью усовершенствования процесса управления потребительской иенностью предложено структурно-логическую схему, которая приводит последовательность действий, которых требует проиесс совершенствования комплекса маркетинга предприятия на рынке услуг.

Ключевые слова: комплекс маркетинга, рынок услуг, товар, цена, распределение, продвижение, персонал, физическое атрибут, процесс.

The article studies evolution of concepts of the marketing mix on the basis of the complex "4P". The expediency of use of the marketing mix " $7 P^{\prime \prime}$ on the services market was proved. Because of the rapid changes in the market environment and consumer value customers, and according to specific market services, comprehensive set of marketing «7P» gradually replacing complex $« 4 P »$, as the more relevant features of the service.

In the article the author's approach to the analysis of efficiency of complex of marketing of the company through a piecemeal consideration of the interaction of the elements of the complex and the consumer in the process of making consumer buying decisions. The peculiarities of work with three elements of the marketing mix were considered-process, physical evidence, people. A system for the formation of measures to improve the provision of services was developed. Methodological support for the analysis of the company's personnel according to the developed of the marketing mix was proposed. Structural-logic scheme of the process improvement of the marketing complex enterprises on the service market was formed. In order to improve customer value management process proposed structural and logical scheme that gives the steps required by the process of improvement of the marketing mix on the market.

Keywords: marketing complex, service market, product, price, place, promotion, people, physical evidence, the process.

Вступ. На сьогоднішній день, в умовах жорсткої економічної кризи утримання ринкових позицій та виживання на ринку $є$ першочерговими завданнями, які постають перед компаніями. Перше, до чого слід звернутися у такій ситуації - це маркетингова політика компанії. Використання маркетингу в країні давно набуло широкої популярності та $є$ невід'ємною частиною діяльності будь-якого підприємства. Виробництво нових товарів, встановлення цінової політики, системи розповсюдження, стимулювання продажів, все це нині підпадає під контроль маркетингових служб i контролюється у відповідності до маркетингової стратегії компанії. Комплекс маркетингу підприємства $є$ основою всієї системи маркетингу і управління комплексом маркетингу стає головним завданням для досягнення успішності на ринку. Але система управління комплексом маркетингу не є універсальною для всіх підприємств, саме тому для випередження конкурентів необхідно шукати нові, оптимальніші підходи до аналізу та вдосконалення комплексу маркетингу підприємства. 
Маркетингова діяльність в сучасних умовах повинна швидко і гнучко реагувати на постійні зміни в оточуючому ринковому середовищі. В процесі пошуку заходів для зростання попиту на продукцію товаровиробників науковці також звертають все більшу увагу на дослідження питань удосконалення комплексу маркетингу.

Вагомий внесок у розроблення теоретичних засад формування та управління комплексом маркетингу підприємства здійснили такі відомі вчені, як Г. Армстронг, Н. Борден, Е. Діхтль, Дж. Еванс, Б. Карлофф, Ф. Котлер, Ж.Ж. Ламбен, М. Портер, Х. Хершген та інші. Серед вітчизняних науковців, які забезпечили розвиток наукових засад маркетингу, необхідно відмітити: Л.В. Балабанову, А.В. Войчака, С.С. Гаркавенко, В.Г. Герасимчука, В.Я. Кардаша, С.В. Крикавського, Н.В. Куденко та інших.

Проведений аналіз наукових праць 3 питань управління комплексом маркетингу показав, що нині актуальними $є$ поглиблені теоретичні дослідження, присвячені проблемі адаптації застосування інструментарію маркетингу до умов різних типів ринку.

Постановка завдання. Не зменшуючи важливості теоретикометодологічних, методичних та прикладних напрацювань, необхідно підкреслити, що певне коло завдань залишилось недостатньо розвинутим. Так, основні дослідження та удосконалення методик проводилися для комплексу «4Р», у той час, як додаткові елементи комплексу маркетингу послуг «7Р» залишилися без належного опрацювання.

Головною метою цієї роботи є формування методики аналізу комплексу маркетингу «7Р», системи удосконалення комплексу маркетингу на підприємстві, та розширений аналіз роботи із елементами комплексу «7Р» персонал, процес, фізичний атрибут.

Методологія. Теоретичною та методологічною основою роботи стали наукові праці провідних вітчизняних та зарубіжних вчених в галузі маркетингу та економіки. Інформаційною базою стали державні та галузеві нормативно-правові документи, дані вітчизняної офіційної статистики, річні та планові звіти i веб-сайти вітчизняних підприємств, їх технічна документація, галузеві та фахові видання і результати власних досліджень автора.

Для реалізації поставлених завдань застосовані ряд методів, зокрема аналіз і синтез, загальнонаукові методи, методи систематизації, порівнянь, спостереження, абстрактно-логічний метод для узагальнення результатів дослідження і формулювання висновків.

Результати дослідження. Особливим підходом до визначення сутності маркетингу $\epsilon$ трактування його 3 позицій «комплексу маркетингу», що розглядається «як сукупність маркетингових засобів, що піддаються 
контролю, які компанія використовує з метою одержання бажаної реакції цільового ринку» [2].

Коли маркетинг почав грунтуватися на виділенні в товарах або послугах окремих характеристик, здатних задовольнити конкретну потребу певного кола споживачів, та на перший план вийшла сегментна орієнтація, у цей час i набув широкого використання комплекс маркетингу або всім відома концепція «4Р»-маркетинг-мікс [4].

На сьогоднішній день, комплекс маркетингу - це одна 3 фундаментальних категорій сучасного маркетингу. Згідно 3 найбільш поширеними трактуваннями, комплекс маркетингу (маркетинг-мікс) - це сукупність маркетингових засобів, певна структура яких забезпечує досягнення поставленої мети та вирішення маркетингових завдань. Цих інструментів досить багато. Дж. Маккарті запропонував об'єднувати їх у 4 групи: продукт, ціна, місце і просування. У літературних джерелах цей підхід отримав назву концепції «4P» (Product, Price, Place, Promotion). Відповідно до цієї концепції, організації в межах маркетингової діяльності розробляють $\mathrm{i}$ реалізують товарну, цінову, збутову i комунікаційну політику. Дана класифікація Маккарті стала загальноприйнятою та найчастіше використовується в процесі управління маркетингом. Маркетинг-мікс за його визначенням представляє собою використовувану у певний момент часу підприємством комбінацію його інструментів, що спрямовані на цільові сегменти ринку на оперативному рівні [3].

Концепція «4Р» одержала підтримку багатьох учених у області маркетингу і в даний час розвивається ними. Так, Ф. Котлер під комплексом маркетингу (маркетінгом-мікс) розуміє набір змінних чинників маркетингу, що піддаються контролю, сукупність яких фірма використовує в прагненні викликати бажану у відповідь реакцію з боку цільового ринку. Основними елементами комплексу маркетингу він вважає: товар, ціну, методи розподілу (розповсюдження) і просування товару [5].

На сучасному етапі комплекс маркетингу $є$ стандартом в теорії та практиці маркетингової діяльності, але через швидкі зміни ринкового середовища та споживчих цінностей покупців концепція «4Р» зазнала деяких доповнень. Розвиток концепцій був зумовлений пошуком такого поєднання інструментів маркетингу, який би забезпечив перевагу фірми на ринку. Зарубіжні та вітчизняні теоретики маркетингу, беручи за основу сформовану концепцію, доповнюють іiі новими елементами, що об'єднуються у такі моделі як «6Р», «7P», «8P», «10Р», «12Р», тощо. Еволюційний розвиток концепції «Р» наведено у табл. 1. 


\section{Розвиток змісту комплексу маркетингу}

\begin{tabular}{|c|c|c|c|}
\hline Комплекс & Елементи & Переклад & Зміст елементів \\
\hline \multirow{4}{*}{$4 \mathrm{P}$} & Product & Продукт & $\begin{array}{l}\text { Товари і послуги, що пропонуються на } \\
\text { ринку }\end{array}$ \\
\hline & Price & Ціна & $\begin{array}{l}\text { Сума грошей, що необхідно сплатити спо- } \\
\text { живачеві для отримання товару, послуги }\end{array}$ \\
\hline & Place & Місце (розподіл) & Збутова діяльність \\
\hline & Promotion & Просування & $\begin{array}{l}\text { Розповсюдження інформації та перекона- } \\
\text { ння покупців у перевагах товарів і послуг } \\
\text { фірми }\end{array}$ \\
\hline \multirow[b]{2}{*}{$5 \mathrm{P}$} & \multicolumn{3}{|r|}{$4 \mathrm{P}+$} \\
\hline & Personnel & Персонал & $\begin{array}{l}\text { Рівень кваліфікації та професіоналізм } \\
\text { працівників }\end{array}$ \\
\hline \multirow[b]{2}{*}{$6 \mathrm{P}$} & \multicolumn{3}{|r|}{$5 \mathrm{P}+$} \\
\hline & Publicity & Публічність & $\begin{array}{l}\text { Популяризація позитивних особливостей } \\
\text { фірми через 3МІ }\end{array}$ \\
\hline \multirow{3}{*}{$7 \mathrm{P}$} & \multicolumn{3}{|r|}{$5 \mathrm{P}+$} \\
\hline & Process & Процес & $\begin{array}{l}\text { Процес вибору товару чи надання якісних } \\
\text { послуг }\end{array}$ \\
\hline & $\begin{array}{l}\text { Physical } \\
\text { Evidence }\end{array}$ & Фізичний доказ & Матеріальне втілення наданої послуги \\
\hline \multirow[b]{2}{*}{$8 \mathrm{P}$} & \multicolumn{3}{|r|}{$7 \mathrm{P}+$} \\
\hline & $\begin{array}{l}\text { Perceptual } \\
\text { psychology }\end{array}$ & $\begin{array}{l}\text { Психологічне } \\
\text { сприйняття }\end{array}$ & $\begin{array}{l}\text { Психологічні асоціації покупця с приводу } \\
\text { фірми та її товарів і послуг }\end{array}$ \\
\hline \multirow{7}{*}{$10 \mathrm{P}$} & \multicolumn{3}{|r|}{$5 \mathrm{P}+$} \\
\hline & People & Люди & Учасники купівлі-продажу \\
\hline & Package & Упаковка & $\begin{array}{l}\text { Засіб зберігання товару та елемент } \\
\text { наочного відображення бренду }\end{array}$ \\
\hline & Purchase & Покупка & $\begin{array}{l}\text { Передумови та наслідки ухвалення } \\
\text { рішення про купівлю }\end{array}$ \\
\hline & Probe & Апробація & Перевірка на практиці \\
\hline & Public & Зв'язки з & Створення позитивного іміджу \\
\hline & Relations & громадськістю & підприємства, продукції, послуг \\
\hline \multirow[b]{2}{*}{$12 \mathrm{P}$} & \multicolumn{3}{|c|}{ 5P+People, Public Relations, Process, Package, Purchase } \\
\hline & $\begin{array}{l}\text { Physical } \\
\text { Premises } \\
\text { Profit }\end{array}$ & $\begin{array}{l}\text { Навколишнє } \\
\text { середовище } \\
\text { Прибуток }\end{array}$ & $\begin{array}{l}\text { Умови створені для ефективного збуту } \\
\text { власної продукції } \\
\text { Дохід за відрахуванням витрат }\end{array}$ \\
\hline \multirow[t]{2}{*}{$4 \mathrm{C}$} & $\begin{array}{l}\text { Customer need } \\
\text { and wants = } \\
\text { Product }\end{array}$ & $\begin{array}{l}\text { Потреби та } \\
\text { побажання } \\
\text { споживача = } \\
\text { Продукт }\end{array}$ & $\begin{array}{l}\text { Нужди та потреби покупця, що } \\
\text { задовольняються придбавши товар фірми }\end{array}$ \\
\hline & $\begin{array}{l}\text { Cost to } \\
\text { consumer }=\end{array}$ & $\begin{array}{l}\text { Витрати } \\
\text { споживача = Ціна }\end{array}$ & Вартість купівлі товару \\
\hline
\end{tabular}




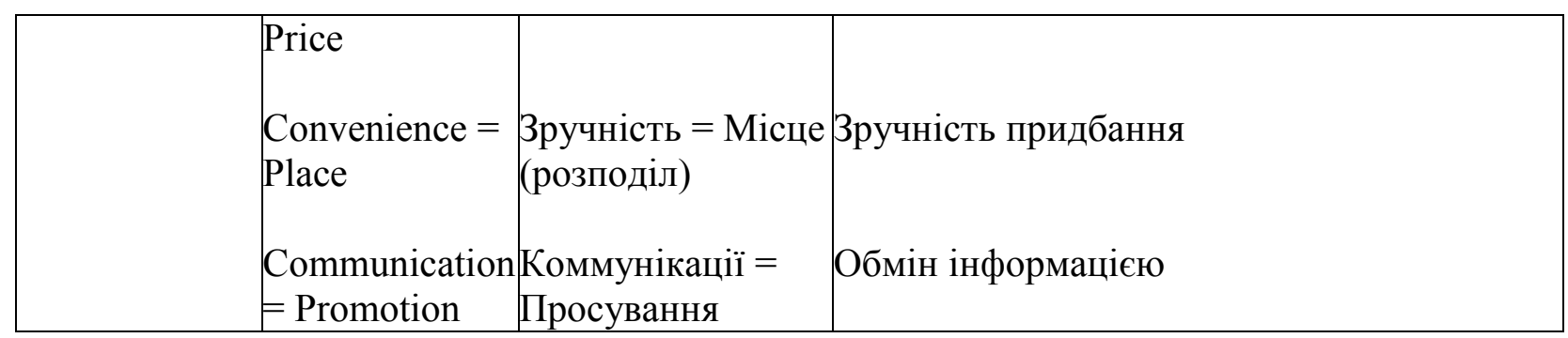

За даними табл. 1, можна стверджувати, що кожний новий зміст за своєю суттю включає ті елементи, які раніше входили у попередній комплекс маркетингу та відбиває зв'язки між його складовими.

Так елементи Personnel (персонал), People (людей), Process (процес), Physical Evidence (фізичний доказ послуги), Perceptual psychology (психологічне сприйняття), Probe (апробацію), Package (упаковку) характеризують Product (продукт). Profit (прибуток) входить до Price. Physical Premises (навколишнє середовище збуту) - до Place. Publicity (публічність), Purchase (покупку), Package (упаковку), Public Relations (Зв'язки 3 громадськістю), Physical Evidence (фізичний доказ послуги) - до Promotion. A концепція «4С» відбиває погляд споживача на комплекс маркетингу виробника, дозволяє аналітикам змістити свій фокус сприйняття, сприяє формуванню цілісності та системності бачення досліджуваного об'єкта.

Активний розвиток сфери послуг став важливою характеристикою минулого століття. Сьогодні третинний сектор економіки вносить вагомий внесок в збільшення добробуту багатьох країн, перш за все країн «золотого мільярда». В середньому близько $70 \%$ ВВП розвинених країн проводиться в секторі послуг, причому темпи зростання цього сектора (16\% в рік) набагато вищі за темпи зростання сфери торгівлі (лише 7\% в рік).

Дослідники американської школи маркетингу, розробляючи модель маркетингу послуг, виходили 3 основного принципу маркетингу - принципу комплексності, за яким маркетинг розглядається як системна єдність відповідних елементів. Для маркетингу товару - це традиційно комплекс чотирьох елементів «4Р»: product (продукт - товар), ргісе (ціна), place (місце, збут, розподіл), promotion (просування). Ці елементи піддаються контролю 3 боку підприємства, взаємозв'язані один з одним і спрямовані на цільового споживача.

Відповідно до специфіки ринку послуг, комплекс маркетингу послуг відрізняється від комплексу маркетингу товарів.

За моделлю М. Бітнер, комплекс «4Р» для маркетингу послуг доповнюється трьома додатковими елементами «Р»: process (процес), physical evidence (матеріальний, фізичний доказ, свідчення, підтвердження), people (люди, персонал, учасники) (рис.1). Передбачається, що комплекс у складі 
семи елементів «7Р»є достатнім для того, щоб охопити усі види діяльності у секторі послуг.

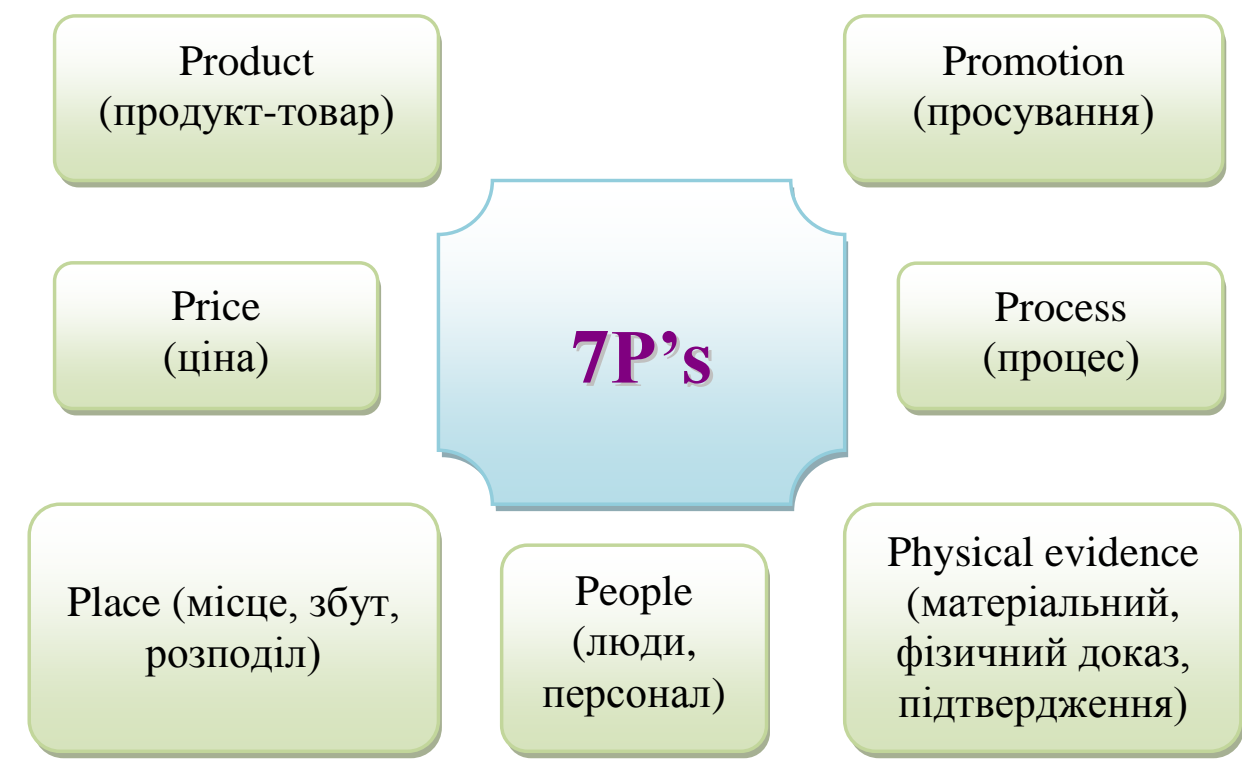

Рис. 1. Складові моделі «7Р» за М. Бітнера

Розширений комплекс маркетингу 7P поступово витісняє 4Р, так як краще відповідає особливостям сфери послуг.

Слід зазначити, що всі три додаткових частини комплексу маркетингу послуг належать, головним чином, до внутрішніх чинників роботи підприємства, а не до його зовнішніх характеристик, як перші чотири частини. Комплекс маркетингу «7Р» визнає, що відбувається всередині підприємства має безпосереднє відношення до маркетингу, отже, крім зовнішнього, не менш важливим $є$ внутрішній маркетинг.

На підприємстві перед менеджментом постає задача - скомпонувати ці 7 елементів так, щоб отримати оптимальний прибуток від реалізації продукції і послуг на ринку. Маркетинговий комплекс повинен бути пристосований до конкретних умов навколишнього середовища і щоб в ньому враховувались вимоги підприємства-виробника, споживачів і відповідного сектора ринку.

Рекомендацією до роботи із комплексом маркетингу підприємства $\epsilon$ його планування не покомпонентно, а поетапно разом із процесом прийняття рішення про покупку споживачем. Такий детальний аналіз дасть можливість знайти недоліки та сильні сторони компанії, зосередитися на елементах, які найбільш відчутно сприймаються споживачем і мають бути виправлені якнайскоріше. Модель взаємодії зі споживачем включає в себе вплив комплексу маркетингу компанії «7Р» на споживача протягом п'яти етапів, які проходить покупець при кожній купівлі (рис. 2). 


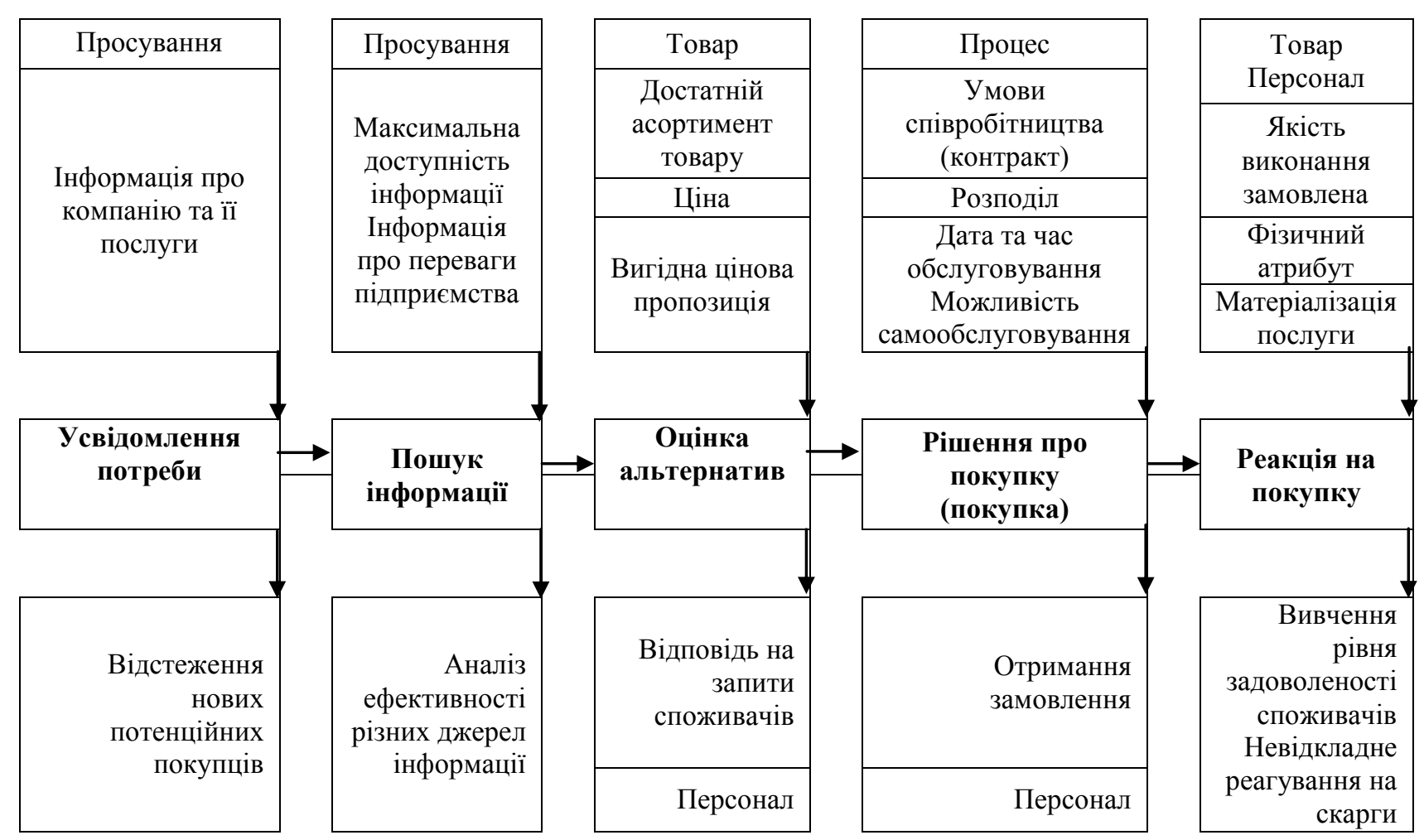

Рис. 2. Модель взаємодії зі споживачем у процесі прийняття ним рішення про купівлю

Такий аналіз дасть можливість прослідкувати за високою ефективністю взаємодії компанії з покупцем на кожному етапі і дасть можливість побачити, які з елементів комплексу маркетингу потребують доопрацювання.

Після проведеного аналізу відбувається зіставлення відповідності існуючого на підприємстві комплексу маркетингу ситуації, що склалася на ринку. Зважаючи на основі невідповідності умовам ринку далі відбувається формування оновленого комплексу маркетингу, який забезпечить реалізацію цілей компанії на ринку.

Формування товарної, цінової, збутової політики та політики просування підприємства широко описані багатьма науковцями та практиками маркетингу. У той же час специфікою надання послуг на ринку промислових пралень $\epsilon$ вирішальна роль персоналу в успішності роботи підприємства. Важливими також $є$ розробка теорії щодо процесу надання та матеріалізації послуги. Тож розглянемо детальніше роботу із елементами внутрішнього маркетингу «7Р» - персоналом, процесом, фізичним атрибутом.

Для вдосконалення процесу надання послуг на підприємстві необхідно дати відповідь на такі питання:

В яких процесах споживачеві потрібно взяти участь, щоб отримати послугу?

Які процеси викликають задоволення, а які дратують?

Чого хочуть споживача від процесу отримання послуги? 
Які процеси потрібні для того, щоб споживач дізнався про вас: передплата, реєстрація в базі даних, особистий контакт, інформація в ЗМI та Інтернеті?

Відповіді на ці питання підприємство може отримати за результатами проведеного експерименту - залучення експерта у якості таємного покупця. За отриманими результатами прописується програма, яка спрямована на удосконалення процесу надання послуг цільовому споживачеві. Для зручності формування програми пропонується використовувати наступну таблицю (табл. 2).

Таблиця 2

Формування заходів з удосконалення процесу надання послуг

\begin{tabular}{|c|c|c|c|c|}
\hline № & $\begin{array}{c}\text { Етап процесу надання } \\
\text { послуги }\end{array}$ & $\begin{array}{c}\text { Виявлені } \\
\text { недоліки }\end{array}$ & $\begin{array}{c}\text { Пропоноване } \\
\text { рішення проблеми }\end{array}$ & $\begin{array}{c}\text { Особливості } \\
\text { імплементації } \\
\text { рішення }\end{array}$ \\
\hline 1 & & & & \\
\hline 2 & & & & \\
\hline 3 & & & & \\
\hline
\end{tabular}

У процесі удосконалення фізичного оточення важливим є креативний підхід. Підприємство має продумати наступні елементи:

1) матеріальний предмет, який може служити для клієнта підтвердженням факту надання послуги. Це досить складно зробити підприємствам на ринку промислових пралень. Варто розглядати нові підходи до упаковки, корпоративні подарунки та ін.

2) те, що оточує споживача в момент придбання послуги. Фізичне оточення дозволяє сформувати правильний імідж компанії, виділити відмінні характеристики продукту. Тут розглядається формування фірмового одягу співробітників, які контактують 3 клієнтами, створення спеціального приміщення для клієнтів на базі пральні, створення фірмового дизайну пунктів прийому ін.

У роботі підприємства сфері послуг одним із основних елементів, що визначає успіх компанії є іiі персонал. Персонал має вплив на кожен 3 елементів комплексу маркетингу «4Р», при цьому мається на увазі не плани $\mathrm{i}$ розробки маркетолога, а звичайні дії робітників підприємства, що так чи інакше визначають роботу комплексу маркетингу підприємства. Таким чином було вирішено розробити модель для аналізу та вдосконалення роботи персоналу, що відноситься до різних елементів комплексу маркетингу (табл. 3). 
Таблиця 3

Аналіз персоналу пов'язаного з реалізацією комплексу маркетингу («4Р») підприсмства

\begin{tabular}{|c|c|}
\hline Товар & Ціна \\
\hline Хто & Хто \\
\hline Ризики & Ризики \\
\hline Вимоги & Вимоги \\
\hline Розподіл & Просування \\
\hline Хто & Хто \\
\hline Ризики & Ризики \\
\hline Вимоги & Вимоги \\
\hline
\end{tabular}

Проведення аналізу за запропонованою моделлю дасть відповідь на питання: хто реально приймає участь у реалізації політики кампанії щодо певного елементу комплексу маркетингу, які ризики можуть бути пов'язані із некомпетентністю даного персоналу, та які вимоги варто висувати до даних робітників у їх компетенціях та методології роботи.

Варто пам'ятати, що співробітники немаркетингових відділів підприємства (відділ розробки та дизайну, транспортування, кадрів та фінансів, служба підтримки, сервісна служба) мають значний вплив на успіх підприємства [1].

За допомогою цієї моделі можна визначити та попередити ризики, які пов'язані із непрофесійністю робітників компанії. Модель дає можливість визначити основні вимоги до роботи усього персоналу, який впливає на результат надання послуги, розробити стандарти обслуговування для всіх співробітників компанії.

Персонал не тільки відіграє важливу роль у взаємодії між постачальником і споживачем, але може бути також джерелом конкурентної переваги послуги. Персонал своєю діяльністю здатний надати компанії конкурентну перевагу, додаючи цінність послузі і підвищуючи ефективність своєї роботи.

Критично важливою для підприємств на ринку промислових пралень $\epsilon$ концепція внутрішнього маркетингу. Суть внутрішнього маркетингу полягає в тому, що відносини компанії і працівників будуються на тих же підставах, що й відносини компанії 3 клієнтами. Керівництво «пропонує» особливий продукт - посаду з іï специфічними правами та обов'язками. Працівник «купує» цей продукт, «оплачуючи» його своєю працею. Відповідно, орієнтація на клієнта доповнюється орієнтацією на «внутрішнього споживача» - співробітника. Завдяки цьому підвищується мотивація співробітників до 
праці, а отже, він може розглядатися як інструмент управління якістю продуктів і послуг.

Основні функціональні напрями, які підприємство може використовувати у сфері внутрішнього маркетингу: організація тренінгів, лідерство та підтримка, внутрішні комунікації та діалог, зовнішні комунікації, планування, заохочення, використання технологій, внутрішні дослідження.

На основі проведеного дослідження було сформовано структурнологічну схему, яка вказує послідовність дій, яких потребує процес удосконалення комплексу маркетингу підприємства на ринку промислових пралень (рис.3).

Планування комплексу маркетингу підприємства починається 3 комплексного дослідження ринку, тому що воно орієнтоване на задоволення потреб споживачів. У ході цього дослідження проводиться вивчення поведінки споживачів, їх смаків та уподобань, потреб, споживчих переваг, мотивів, що спонукають їх купувати товар, і це дозволяє підприємству якнайкраще задовольняти їх потреби. Дослідження ринку також передбачає вивчення і прогнозування попиту на товар, аналіз цін і товарів конкурентів, визначення місткості ринку і частки підприємства на ньому. Такий аналіз допомагає оцінити ринкові можливості і визначити привабливий напрям маркетингової діяльності, на якому підприємство може набути конкурентних переваг. 


\section{- Проведення комплексного аналізу рннку}

- стан, тенденщії рипку, аналіз конкурентів, що працюють на даному ринку, потенщійні учасники ринку, товари - субститути, спожлвачі та постачальнпки.

\section{- Аналіз маркетингової діяльності підпрнємства}

- слстема маркетипгової інформації, управління маркетипгом, аналіз існуючого комплексу маркетингу підприємства, аналіз ресурсів та потужностей підприємства

- Проведення дослідження для оцінки напрямів коригування комплексу маркетннгу підпрнємства

\section{- Формування удосконаленого комплексу маркетингу} підприемства за моделлю 7 Р

- розробка товарної стратегії

- визначення стратегії ціноутворення

- визначення засобів розповсюдження товару

- визначення стратегії просування

• удосконалення процесу надання послуги

- створення фізгчнгх атребутів для матеріалізації послуги

- роботаз персоналом компанії

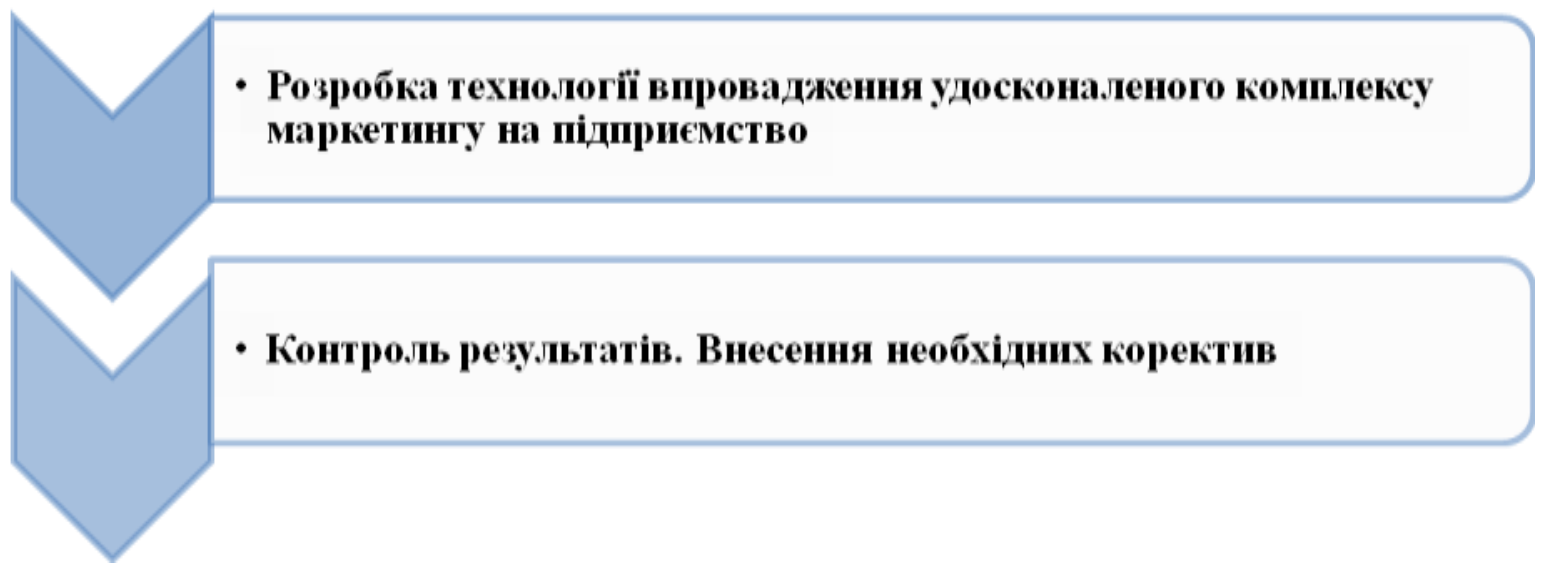

Рис. 3. Процес удосконалення комплексу маркетингу підприємства 
Водночас ведеться пошук своїх потенційних споживачів, потреби яких підприємство прагне задовольнити. Притому використовується дуже важливий маркетинговий прийом - сегментація ринку, тобто розподіл споживачів на групи на підставі різниці в їх потребах, характеристиках та поведінці. Після цього приймається рішення щодо позиціонування товару на ринку. Тепер підприємство може розпочинати розроблення комплексу маркетингу.

У ситуації, коли комплекс маркетингу підприємства потребує удосконалення, першочерговим після проведеного дослідження $\epsilon$ аналіз існуючої системи комплексу маркетингу, виявлення іiі слабких сторін та недоліків для наступної цільової роботи з певними елементами. У цьому випадку поетапно аналізується кожен із елементів комплексу маркетингу підприємства на ринку промислових пралень.

Після чого відбувається формування удосконаленого комплексу маркетингу підприємства за моделлю «7Р», розробляється технологія впровадження удосконаленого комплексу маркетингу на підприємство. Результати впровадженого комплексу маркетингу відстежуються, аналізуються, до стратегій вносяться необхідні корективи.

Висновки. Через швидкі зміни ринкового середовища та споживчих цінностей покупців, а також відповідно до специфіки ринку послуг, розширений комплекс маркетингу «7Р» поступово витісняє комплекс «4Р», так як краще відповідає особливостям сфери послуг. За моделлю «7Р», традиційний комплекс «4Р» доповнюється трьома додатковими елементами «Р»: process - процес, physical evidence - фізичний доказ, people - люди, персонал; які належать, головним чином, до внутрішніх чинників роботи підприємства, а не до його зовнішніх характеристик, як перші чотири частини. Комплекс маркетингу «7Р» визнає, що відбувається всередині підприємства має безпосереднє відношення до маркетингу.

Для аналізу ефективності комплексу маркетингу підприємства у роботі було запропоновано модель впливу елементів комплексу маркетингу «7Р» на споживача у процесі прийняття рішення про купівлю. На відміну від традиційного комплексу маркетингу «4Р», комплекс маркетингу для ринку послуг має недостатню методологічну базу, це зумовило розробку у роботі системи аналізу роботи персоналу, що реалізує розроблений комплекс маркетингу «4Р» підприємства та методику для формування заходів 3 удосконалення процесу надання послуг.

За результатами дослідження сформовано структурно-логічну схему, яка наводить послідовність дій, яких потребує процес удосконалення комплексу маркетингу підприємства. Запропонованої схема містить наступні етапи: проведення комплексного аналізу ринку, аналіз маркетингової діяльності підприємства, проведення дослідження для оцінки напрямків 
коригування комплексу маркетингу підприємства, формування удосконаленого комплексу маркетингу підприємства за моделлю «7Р», розробка технології впровадження удосконаленого комплексу маркетингу на підприємство, відстеження результатів, внесення необхідних коректив.

\section{Література:}

1. Johnson, E. Are goods and Services Different? An Exercise in marketing Theory: Unpublished Ph.D. dissertation. - Washington University, 1969.

2. Артімонова I.В. Концепція маркетинг-міксу як основа програмно-цільового підходу до організації маркетингової діяльності підприємства / І.В. Артімонова // Актуальні проблеми економіки. - 2010. - № 4. - С.94 - 101.

3. Ілляшенка С.М. Маркетинг для магістрів: посібник/ за заг. ред.. С.М. Ілляшенка. Суми: ВТД «Університетська книга», 2007. - 928с.

4. Ілляшенко Н.С. Організаційно-економічні засади інноваційного маркетингу промислових підприємств: монографія / Н.С. Ілляшенко. - Суми: «Вид-во СумДУ», 2011. - 192c.

5. Котлер Ф. Маркетинг менеджмент. Анализ, планирование, внедрение, контроль. - 2-е рус. изд.; 9-е международное изд.. - СПб.: Питер Ком, 1999. - 896 с. 